\title{
Exploring the Herding Behaviour in Indian Mutual Fund Industry
}

\author{
Ms. Archana Patro \\ Participant, Fellow programme in Management \\ Indian Institute of Management Indore \\ Prabandh Shikhar, Rau-Pithampur Road, Indore 453331 MP, India \\ E-mail: f09archanap@iimidr.ac.in \\ Prof. A. Kanagaraj \\ Faculty of Finance and Accounting \\ Indian Institute of Management Indore \\ Prabandh Shikhar, Rau-Pithampur Road, Indore 453331 MP, India \\ E-mail: Kanagaraj@iimidr.ac.in
}

\begin{abstract}
Received: March 6, $2012 \quad$ Accepted: April 5, $2012 \quad$ Published: June 1, 2012
doi:10.5296/ajfa.v4i1.1478 URL: http://dx.doi.org/10.5296/ajfa.v4i1.1478
\end{abstract}

\begin{abstract}
The present study analyzes the trading activity of Indian mutual funds and investigates whether Indian mutual fund managers are engaged in herding behaviour. Results are compared with previous studies in mature as well as developing markets to determine the level of maturity of the Indian capital market. Measure of herding developed by Lakonishok et al. (1992) has been used. The study found strong evidence of herding in the overall sample. Managers herd primarily when they trade in large capitalization stocks or stocks that belong to the most famous indices. The herding effect seems to affect both purchases and sales of stocks. The level of herding is more in Indian stock market as compared to developed markets. Furthermore, the Indian mutual funds tend to herd more often when purchasing than when selling a stock, and when trading large stocks. The study will contribute to the discussion regarding market efficiency and traditional asset pricing models validity. Evidence on herding by institutional investors, could explain whether there are different types of
\end{abstract}




\section{Macrothink}

Asian Journal of Finance \& Accounting ISSN 1946-052X

investors having different trading pattern. Investigating herding on Indian mutual funds would help researchers, investors, traders and regulators.

Keywords: Mutual fund, Herding, Behavioural finance, LSV measure, Institutional investors 


\section{Introduction}

As we go through the underlying assumptions for Efficient Market Hypothesis (EMH) and the Capital Asset Pricing Model (CAPM), it triggers certain questions among the researchers about the validity of these assumptions in the real world. (Frankfurter and McGoun, 2001) says this is because the assumptions imply investors are totally keen, penetrating and rational in calculating the numbers that are required for making investment decisions. It might be the reasons of their simplicity and suitability for advanced mathematical models, these assumptions have formed a foundation that had not been questioned for several decades.

Behavioural Finance has upset the very foundation of traditional finance theories. According to Behavioural Finance it is the vary phenomena of human natural tendency to behave differently to different situations. One such phenomenon is Herding. It is defined as heavy buying or selling by specific groups of investors in the same stocks over a period of time. It is defined as a group of investors following each other into or out of the same securities over some period of time (Lakonishok et al. 1992; Sias 2004).Herding becomes more important if finance professionals and experts exhibit such behaviour, as they are supposed to be the most rational and efficient persons according to the traditional approach. If these individuals will not verify the traditional approach with their behaviour, the concept cannot hold at all.

There is a popular belief that institutional investors are irrational herding into and out of stocks without fundamental justification. Because of high trading volumes institutional herding is suspected to dilute the information quality of stock prices, exacerbate stock price volatility, and destabilizes capital markets by driving prices away from fundamentals (Scharfstein and Stein, 1990). This paper test for herding by Indian mutual funds. The present study is focused on mutual funds as majority of corporate equities are held by them, and their trade volume proportion is higher for institutional herding to be observed.

The Indian mutual fund industry has witnessed a significant growth in the past few years driven by several favourable economic and demographic factors such as rising income levels and the increasing reach of Asset Management Companies (AMCs) and distributors. Further enabling support from the regulator SEBI and proactive initiatives from the industry bodies CII and AMFI, which are likely to be the key components in defining the future shape of the Indian Mutual, fund Industry as said by Abizer Diwanji Head Financial Services KPMG India. The low penetration levels combined with rapid growth in the assets under management in recent years will find a place for the high growth potential of the Indian mutual fund industry. India has been amongst the fastest growing markets for mutual funds since 2004, witnessing a CAGR of 29 percent in the five-year period from 2004 to 2008 as against the global average of 4 percent industry Assets under management is likely to continue to grow in the range of 15 to 25 percent from the period 2010 to 2015 based on the pace of economic growth, KPMG (2009)

Looking at the importance of mutual funds in Indian economy, the purpose of this study is to investigate to what extent the Indian mutual fund industry exhibit herding behaviour. The Paper also analyze the data in relation to the results obtained from previous studies in mature as well as developing markets, and thus provide financial research with valuable insights into 
the level of maturity of the Indian capital market. Thus the paper contributes to the body of literature by analyzing the herding behaviour for a very recent time period, giving fresh estimates of herding based on data on a changing Indian financial market.

\section{Literature Review}

Herding refers to the human tendency to imitate the behavior of others, which leads to a group of people acting in a similar way (Lemieux, 2003, 2004). The tendency to trade in the same direction can be categorized into intentional and unintentional herding. Scharfstein and Stein (1990) tried to explain intentional herding by stating that fund managers may disregard their private information and trade with the crowd due to the reputation risk of acting differently from their peers. An alternative theory points out that fund managers might gather private information from the prior trades of better-informed managers and trade in the same direction (Bikhchandani et al., 1992). The approach to unintentional herding by Froot et al.(1992) is that managers may trade together solely because they receive correlated private information, e.g. by analyzing the same indicators.

Examining herding behavior can grant investors a higher degree of understanding regarding the price formations in financial markets. Chang et al. (1999) show the study of herding behavior is important as share prices are substantially affected by market participants' investment behavior. It has been linked to some market inefficiency, which cannot be explained by the Rational Asset Pricing Model, when an investor's investment decision is based on collective information rather than private information, it might drive stock away from its fundamental value. Therefore, herding behavior is a signal of market inefficiency. Consequently, the existence of herding behavior suggests that the real world market is not as efficient as the Rational Asset Pricing Model might expect.

Extensive research has investigated the level of herding behavior in developed as well as developing Markets. The findings are contradictory from country to country. Christie and Hwang (1995) have found that there is no significant herding in US markets, as securities return dispersion increases instead of decreasing during periods of large price movements. Chang, et al. (1999) displays similar results, namely there is no significant level of herding in the United States, Hong Kong and Japan. Caparrelli, et al., (2004) also found that herding is only present during extreme market conditions in the Italian market.

Furthermore, Nofsinger and Sias (1999) use their own approach and show that herding behavior is in fact present in US market as they find that there is a strong positive correlation between changes in institutional ownership and excess returns measured over the same period in the market. These findings provide evidence that there has been a high level of herding behaviour among institutional investors in US markets. Iihara, et al., (2001) examine the herding behaviour observable in three groups of investors individual, institutional and foreign, in the Tokyo Stock Exchange (TSE) using the approach of Nofsinger and Sias (1999). Their finding illustrates that Japanese individual and institutional investors are more likely to engage in Positive Feedback Trading Strategies and are therefore more likely to herd, while foreign investors' investment decisions tend to be based on information. Therefore, their result is consistent with Nofsinger and Sias (1999). 
For instance, Demirer and Kutan (2005) investigate the potential existence of herding behavior in Chinese stock markets by using the approach proposed by Christie and Huang (1995). They examine both A-share and B-share in Shanghai and Shenzhen stocks markets. In addition, they expect that herding levels would be different between the Shanghai and Shenzhen Exchanges because of different market characteristics, namely the former has a larger market size; the former consists of large state-owned enterprises, while the latter consists of mainly manufacturing and export companies; and the former is considered as being more informed.

Thus, they expect that there would be a higher level of herding behavior in the Shenzhen stock market. Their research results are similar to that of with Christie and Hwang (1995) and being favorable towards Rational Asset Pricing Models. Nonetheless, Tan et al. (2007) find conflicting result in their study of herding behavior in both Shanghai and Shenzhen stock exchanges by following the CSAD approach. Their finding shows that herding behavior exists in both Shanghai and Shenzhen, A-share and B-share markets. Chang et al. (1999) also demonstrate that there is evidence of herding behavior in South Korea and Taiwan. They argue that this behavior may be a result of incomplete information disclosure in emerging markets and the greater importance of macroeconomics with regard to investor decision-making, in turn making them more likely to herd around.

Institutional investors may herd not so much because of imperfect information, although this might happen as well, but primarily (and for the long term) due to reputational concerns (Bernhardt et al. 2006) and compensation structures (Clarke and Subramanian, 2006). An investment manager will probably not face personal professional damage if he fails when the others have failed as well, but is very likely to lose his job if he significantly under performs the market (Hirshleifer and Teoh, 2003). Consequently, this could lead to permanent behavioral biases for the investment managers, since a risk-averse manager has a large incentive to follow the market consensus to avoid professional implications.

Krous (1972) et al. first uses 229 monthly data of mutual funds and bank trust institutions from Jan.1968 to Sep. 1969 to test institutional group behavior. They find that mutual funds tend to imitate the strategies of their more successive counterparts, and they call it "Follow leaders" Strategy. Lakonishok, Shleifer and Vishny (1992) use the percentage of investors that are in one-side markets to study whether there exists herding between managers of stock funds exemption from duty in America, and they further test this based on classifications according to sizes of shares, historical performance and asset scale of funds, etc. They find that these funds do not exhibit significant herding but there exists a little herding in transactions of stocks of small companies. Grinblat, Titman and Wemers (1995) study on portfolios of 274 mutual funds in a period of 1974-1984 and get a similar result. Generally, LSV method is most widely used for its simplify and the availability of data. Wemers (1999) takes all the funds in American stock markets between 1975-1994 as the object of the study, and find herding is very obvious for total Funds based on a further study, and the herding tendencies of different funds have great differences. 
ShiDonghui (2001) analyzes the herding behavior of Chinese investment funds, and the results show that more than $75 \%$ of funds are at the same side in markets, herding is very serious. Júlio Lobão(2002) test for herding by Portuguese mutual funds over the period of 1998 to 2000 and found strong evidence of herding behaviour for Portuguese mutual funds. Furthermore, their results suggest that the level of herding is 4 to 5 times stronger than the herding found for institutional investors in mature markets. The herding effect seems to affect, as likely, purchases and sales of stocks. There seems to be a stronger tendency to herd among medium-cap funds rather than very large or very small funds, and among funds with fewer stocks. Lastly, herding seems to decrease when the stock market is doing well or is more volatile.

Yuan ke and Chen Hao (2003) test completely the herding of investment funds in stock markets of Shanghai and Shenzhen by referring to the method (LSV method) of Lakonishok (1991), and find there exists strong herding between mutual funds in Chinese stock markets. Qi Bin et al. (2006) use the classic LSV method and the method extended by Wermers to study empirically behaviors of institutional investors of which the preventatives are mutual funds in China.

Angelo Manganaro (2007) investigates the tendency to herd by 124 Swedish equity mutual funds over the period of 2000 to 2007. By employing the measure developed by Lakonishok et al. (1992) they found strong evidence of herding in the overall sample. Nikolaos Theriou1 (2010) analyzed portfolio holdings of 31 mutual funds using the methodology proposed by Lakonishok et al. (1992). The study concludes that mutual fund managers undoubtedly herd, with the extent of herding being irrelevant to the price movements observed in the market. Managers herd primarily when they trade in large capitalization stocks or stocks that belong to the most famous indices.

Empirical studies on Herding in Indian Context are very few.Gokhan Sonaer (2011) examines whether herding by actively managed equity funds affects their performance. First the effect of herding on stock returns is re-examined and evidence is found that, during the herding quarter, stocks bought intensely by herds outperform stocks sold intensely by herds. Controlling for subsequent quarter herding, this performance difference reverses, an indication that herding drives prices away from their fundamental values. It is also shown that herding funds benefit from this activity during the quarter in which they herd. Introducing the concept of leader and follower funds this study shows that the subsequent quarter performance of funds that lead the herd is superior to that of follower funds.

Sanjay Sehgal and Neeta Tripathi (2009) in their paper empirically evaluate if Foreign Institutional Investors (FIIs) adopt positive feedback and herding strategies in the Indian environment and found that FIIs exhibit return chasing behavior when they use monthly data. However, they do not seem to be working on the positive feedback strategy when they used daily files. This may be owing to the fact that they wait for the market information to crystallize and do not react to it in an instantaneous manner. The study also observes that the FIIs display strong herding behaviour based on quarterly shareholding pattern. The herding behaviour seems to be stronger at the aggregate level than at the individual stock level. This 
may be explained by the fact that FIIs are more cognizant of corporate fundamentals at the individual stock level. Further, the market cycle behaviour may vary from such cycles for individual stocks. Their findings have strong implications for domestic financial institutions, portfolio managers, wealth managers and other investors as well as market regulators who wish to have better understanding of FIIs behaviour as the later are the dominant investors in the Indian equity market.

Paulo Lao and Harminder Singh (2011) in their study examine herding behavior in the Chinese and Indian stock markets. The study employs the Cross Sectional Absolute Deviation (CSAD) approach proposed by Tan, Chiang, Mason and Nelling (2008) to measure herding behavior. The findings suggest that herding behavior exists in both the Chinese and Indian stock markets depending on some market conditions. In the Chinese market, herding behavior is greater when the market is falling and the trading volume is high. On the other hand, in India the study finds herding behavior during the up market. Herding behavior is more predominant during large market movements in both markets. Relatively, there is lower prevalence of herding behavior detected in the Indian stock market. However, Chinese and Indian stock markets are believed to be riskier and less mature than the developed stock markets.

Even though the herding behavior has been examined in some studies, we have tried to contribute to the literature by proving the evidences of herding in Indian Mutual funds. Through this paper the present study covers a recent time period, to our knowledge, not investigated before in Indian Context

\section{Objective of the Study}

The following hypotheses are to be tested in the study.

Hypothesis 1: The Indian mutual funds exhibit herding behavior.

Hypothesis 2: Higher level of herding is found in the trading of small capitalization stocks.

Managers of larger funds have more resources and should therefore be able to extract more accurate private information. Smaller funds with fewer resources will more often have to mimic each other's trading decisions, Bikhchandani et al. (1992).

Hypothesis 3: The tendency to herd increases with the number of funds trading a specific stock within the period.

The expected level of herding in the Indian fund market is higher than for more developed Markets. Less developed markets have lower information efficiency; therefore the investors may base more of their decisions on information from the trades of their peers, Bikhchandani et al. (1992).

\section{Research Methodology}

The database created for the analysis of the study consists of the portfolio holdings of 30 Indian domiciled equity mutual funds. While selecting the sample, certain criteria have been followed. Schemes which are in operation and are non index equity diversified have been 
selected.Futher growth funds were included in the sample. The target sample of the study was collected from the website of The Association of Mutual Funds in India (AMFI).Portfolio holdings database quarter wise from the quarter June2009 to June 2011, i.e. for 10 quartes was created for the study. After extracting required information from the first and the last quarter of holdings, the remaining sample covers 9 quarters over the period of March 2009 to June 2011.Over the whole sample size of 500 different Indian stocks are traded by at least one fund. The number of stocks within a quarter traded by at least one fund summed over the total period provides with 1893 stock-quarters. Finally, the dataset consists of 8256 observations of changes in stock holdings in Indian equity by the funds.

The study uses the measure of herding designed by Lakonishok et al. (1992), the so-called LSV measure. Lakonishok Schleifer Vishny (LSV, 1991) can be regarded as the pioneers of empirical tests of herding behaviour this is the measure most widely used in empirical studies of mutual fund herding behaviour.

The LSV measure estimates the degree of correlated trading among a specific group of investors. Herding behavior is defined as the average tendency of mutual funds to trade a given asset (stock) in the same direction under the same time period above what would be expected if the funds were trading independently.

The LSV herding measure, $H M$, for stock $i$ in period $t$ is defined as:

$$
\mathrm{HM}_{\mathrm{i}, \mathrm{t}}=\left|\mathrm{p}_{\mathrm{i}, \mathrm{t}} \mathrm{p}_{\mathrm{t}}\right|-\mathrm{AF}_{\mathrm{i}, \mathrm{t}}
$$

$$
\text { Where } \mathrm{pi}, \mathrm{t}=\frac{\mathbf{B i}, \mathrm{t}}{\mathbf{B i}, \mathrm{t}+\mathbf{S i}, \mathrm{t}} \text { and } \mathrm{pt}=\frac{\mathbf{L}_{l=1}^{m} \mathbf{p l}, \mathrm{t}}{\mathrm{n}}
$$

$B i, t(S i, t)$ is the number of funds that buy (sell) the stock $i$ during the period $t$. Thus, $p i, t$ is the proportion of funds trading the stock $i, t$ during the period $t$ that were buyers. $p t$ is the average proportion of trades over all funds that were purchases in the period $t$. $p t$ corrects for the expected proportion of buyers under the null hypothesis of independent trading. It is calculated separately for each time period, since it could depend on the net capital inflows to the funds during the period.

The first part of the LSV measure, $|p i, t-p t|$, is defined in absolute value and as a result the expected value would under random variation differ from zero. The adjustment factor, AFi corrects for this randomness. $A F i$, is the expected value of $|p i, t-p t|$ estimated under the assumption that the direction of the trades follows a binominal distribution with $B i$, and $t S i, t$ as Possible outcomes. Under the null hypothesis of independent trading the probability of $\mathrm{Bi}$, equals

Pt . The adjustment factor accounts for bias that would occur in $|\mathrm{pi}, \mathrm{t}-\mathrm{pt}|$ for stocks traded by a low number of funds. 
A positive value of HMi $t$ gives evidence of herding within a stock-quarter. The calculated values

of HMi,t are averaged for a given subgroup of funds and then over time periods. The adjustment factor and $p t$ for each subgroup of funds are based only on the trading of that subgroup. The measure HMi,t is expected to be calibrated to zero, if no herding actually exists. Since the first expression of the LSV measure HMi, $\mathrm{t}$ is defined in absolute value (|pi,t - pt|), without inclusion of the adjustment factor AFi,t, the measure is likely to take positive values, even where no herding exists.

The ordinary LSV measure does not take into account if the herding behaviour is more pronounced in one direction of the trading. Wermers (1999) modified the measure and designed a buy-side and a sell-side herding measure, BHMi,t and SHMi,t respectively. The measures are calculated in the same manner as the ordinary LSV measure, but conditioned:

$$
\mathrm{BHM}_{\mathrm{i}, \mathrm{t}}=\mathrm{HM}_{\mathrm{i}, \mathrm{t}} \mid \mathrm{pi}, \mathrm{t}>\mathrm{p}_{\mathrm{t}}
$$

$$
\mathrm{SMEi}, \mathrm{t}=\mathrm{HMi}, \mathrm{t} \mid \mathrm{pi}, \mathrm{t}<\mathrm{pt}
$$

The BHMi,t measure includes the stock-quarters where the tendency to buy, pi,t, is higher than the average tendency, $p t$, for the period. The SHMi,t measure calculates herding within the stock quarters where the tendency to buy is lower than the average tendency.

\section{Data Analysis and Discussion}

\begin{tabular}{|c|c|c|c|c|c|c|c|c|c|c|}
\hline \multicolumn{11}{|c|}{ Quarter Wise Portfolio data } \\
\hline Quarters & Q1 & Q2 & Q3 & Q4 & Q5 & Q6 & Q7 & Q8 & Q9 & Average \\
\hline \multicolumn{11}{|c|}{ A. Fund counts } \\
\hline $\begin{array}{l}\text { No. Of active funds in } \\
\text { database }\end{array}$ & 30 & 30 & 30 & 30 & 30 & 30 & 30 & 30 & 30 & 30 \\
\hline \multicolumn{11}{|c|}{ B. Net asset fund value } \\
\hline $\begin{array}{l}\text { Total net assets of funds } \\
\text { (Avg) in percentage }\end{array}$ & 98.20 & 99.58 & 99.07 & 96.03 & 95.62 & 92.89 & 69.68 & 83.84 & 26.75 & 84.62 \\
\hline \multicolumn{11}{|c|}{ C.Asset counts } \\
\hline $\begin{array}{l}\text { Number Indian stocks } \\
\text { held per fund }\end{array}$ & 40 & 42 & 38 & 36 & 32 & 30 & 28 & 34 & 37 & 35.222 \\
\hline \multicolumn{11}{|c|}{ D. Trading statistics } \\
\hline Total number of trades & 923 & 952 & 918 & 956 & 999 & 1003 & 952 & 800 & 753 & 917.33 \\
\hline
\end{tabular}

Table 1. Summary Statistics for Indian Equity Mutual fund Holding database (June 2011-09) 


\begin{tabular}{|l|l|l|l|l|l|l|l|l|l|l|l|}
\hline Total trades that are buys & 326 & 267 & 294 & 406 & 358 & 392 & 383 & 313 & 249 & 332 \\
\hline $\begin{array}{l}\text { Percent of trades that are } \\
\text { buys }\end{array}$ & 35.32 & 28.04 & 32.02 & 42.46 & 35.83 & 39.08 & 40.23 & 39.13 & 33.07 & 36.13 \\
\hline \multicolumn{8}{|c|}{ E.Number of stocks traded by } \\
\hline$\geq 1$ Fund & 179 & 173 & 161 & 165 & 165 & 188 & 173 & 139 & 152 & 166 \\
\hline$\geq 2$ Funds & 72 & 31 & 18 & 12 & 23 & 21 & 20 & 19 & 22 & 26 \\
\hline$\geq 5$ Funds & 18 & 4 & 4 & 7 & 8 & 12 & 8 & 11 & 9 & 9 \\
\hline$\geq 10$ Funds & 2 & 3 & 2 & 2 & 8 & 3 & 4 & 6 & 5 & 4 \\
\hline
\end{tabular}

NOTES:

The Indian Equity mutual fund holdings database of my sample contains of portfolio holdings data from the period March 2009 to June2011.Summary statistics of the funds in the sample are reported above as for the first quarter within each year and for the average values of the overall sample in the rightmost column. Panel A records how many funds counted for in each quarter. Panel B presents the total net assets held by the funds in the dataset. Panel C displays summary statistics on the average number of Indian stocks held per fund. Panel D presents trading statistics of the total number of trades, the proportion of the trades that are buys and the number of distinctive stocks traded by at least a given number of funds within the quarter.

Table above displays summary statistics of the holdings in the Indian equity mutual fund database. The average number of funds trading during a quarter is 30 mutual funds. The number of stocks in funds peaks with 42 different stocks in their portfolio in the first quarter of the year 2011. The drop before 2010 is consistent with mergers of some stocks in the funds during that period. Therefore the average total net asset value of the funds within a quarter has also been increased due to the more equity holdings of the mutual funds. On an average it can be seen that, there is an increasing trend in the trade quantity by the funds in India. In the majority of quarters the purchases outweighed the sales, with a total average of trades that were buys of 54.3 percent. In the last panel the number of distinctive stocks traded within a quarter by at least a certain number of funds is presented. The average number of stocks within a quarter traded by at least 1 fund is 166 . The number of stocks traded decreases substantially between each level of minimum funds.

\section{Findings of the Study}

The study came out with an overall herding measure of 13 for the Indian Mutual fund Industry. The results of the analysis provide evidence of herding in the Indian Mutual Funds, consistent with findings of other studies for developing markets.

Table 2. Mutual funds quarter wise Mean Herding measure from March09 to June 2011 


\begin{tabular}{|l|c|c|}
\hline \multicolumn{1}{|c|}{ Quarters } & $\begin{array}{c}\text { No of Stocks } \\
\text { traded }\end{array}$ & LSV measure \\
\hline March11-June11 & 179 & 15.56 \\
\hline Dec10-March11 & 173 & 14.42 \\
\hline Sep10-Dec10 & 161 & 9.50 \\
\hline June10-Sep10 & 165 & 10.72 \\
\hline Mar10-June10 & 165 & 12.15 \\
\hline Dec09- March10 & 188 & 13.76 \\
\hline Sept09-Dec09 & 173 & 12.15 \\
\hline June09-Sept.09 & 139 & 7.85 \\
\hline Apri109-June09 & 152 & 25.36 \\
\hline
\end{tabular}

Above is the data for the herding measure for each quarter that I have calculated. We can observe from the data there is a clear tendency of Herding in Indian Mutual funds. The Herding was highest in the quarter of June 2009 and then suddenly decreased again coming to the value of 15 by the quarter june2011. The study only shows the evidence of herding but the reason behind the same has yet to be explored in further extension of the study.

The table below presents the results from studies conducted using the LSV measure of herding. Grinblatt, Titman and Wermers (1995) investigate the behaviour of 274 mutual funds and they find only weak evidence of herding. When imposing a higher number of minimum funds active in a stock, their computed figures of herding behaviour increase and are highest among growth and income funds. The study by Wermers (1999) is the most extensive, with a remarkable 2424 different funds in the sample. He obtains a low level of herding among mutual funds for the overall sample in the period 1975 to 1994. When dividing into subgroups formed by investment objective he finds higher herding tendency among growth-oriented funds. Also, the effect of herding in small and past-winner stocks seemed to be more prominent. The 268 UK mutual funds investigated by Wylie (2005) showed a similar tendency to herd as for the US investors. As noted above, the results from less developed markets, as the Portugal and Polish financial markets could be considered to be, present a much higher level of herding behaviour. The latest study conducted on herding behaviour is by Walter and Weber (2006) on a sample of 60 German mutual funds. Their figures of herding are close to those from the mature markets.

Table 3. Summary of results of the LSV measure of herding in previous studies

\begin{tabular}{|l|l|l|l|l|}
\hline Study & Market & Period & $\begin{array}{l}\text { Fund } \\
\text { counts }\end{array}$ & $\begin{array}{l}\text { No. Of funds } \\
\text { trading Fund counts } \\
\geq \mathbf{1}\end{array}$ \\
\hline Lakonishok et al (1992) & USA & $85-89$ & 769 & 2.7 \\
\hline Grinblatt et al.(1995) & USA & $74-84$ & 274 & 2.5 \\
\hline
\end{tabular}




\section{Macrothink}

\begin{tabular}{|l|l|l|l|l|}
\hline Loboa and Serra (1998) & Portugal & $98-00$ & 32 & 11.38 \\
\hline $\begin{array}{l}\text { Voronkova and Bohl } \\
(2005)\end{array}$ & Poland & $99-02$ & 17 & 14.6 \\
\hline Walter and Weber (2006) & Germany & $98-02$ & 60 & 2.67 \\
\hline Present Study & India & $2009-11$ & 30 & 13.49 \\
\hline
\end{tabular}

\section{NOTES}

The column Fund counts displays the number of distinctive funds used in the different studies. The number of funds trading indicates the minimum number of active funds within a stock quarter to be included in the computed average herding value

When a graph is plotted using the LSV measure that was calculated with from various quarters Trend of Herding can be observed. It was much higher in the year 2009 and then decreased and slightly increased thereafter. But there is a positive sign of existence of herding during all the quarters of the sample period.

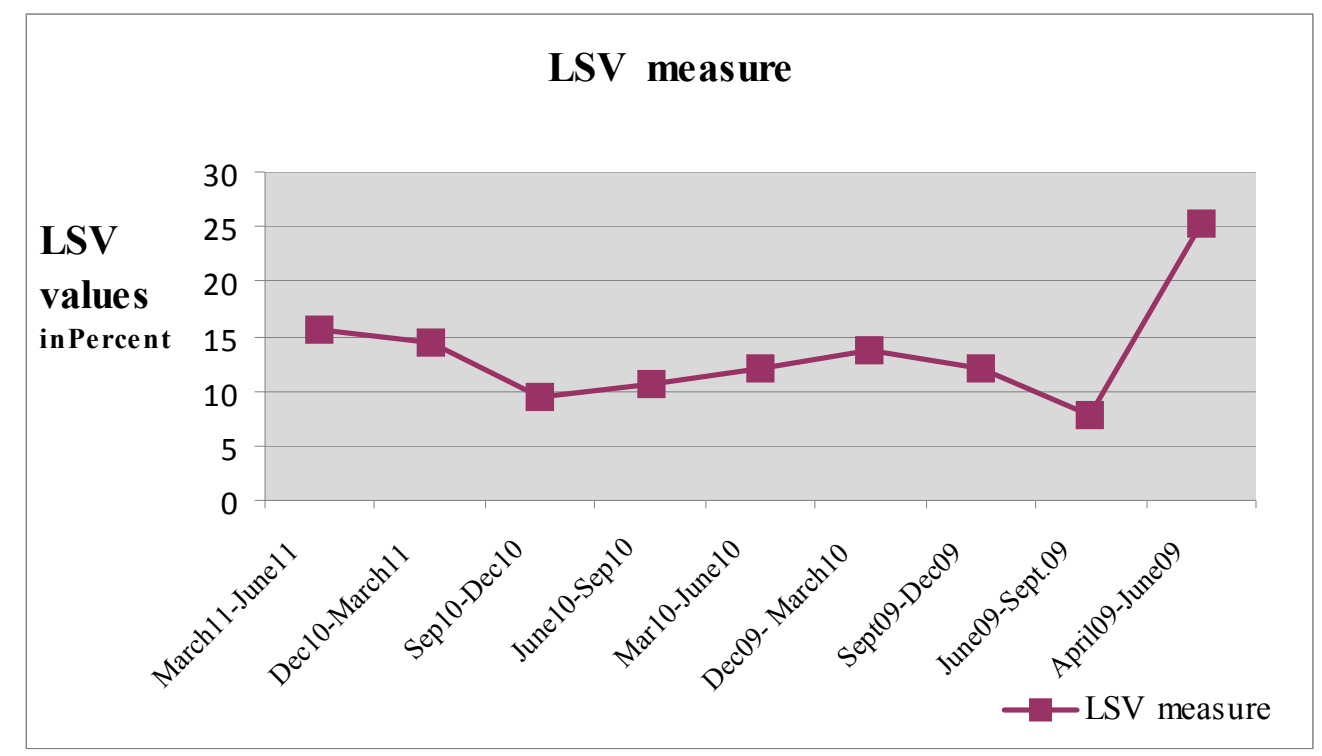

Graph1. The trend of Herding Measure over the quarters

Table 4. Buy Side and Sell side level of Herding 
Mean buy- and sell-herding levels

[BHM and SHM in percent]
For number of Funds Trading in the quarter $>1$

\begin{tabular}{|l|c|}
\hline \multicolumn{2}{|c|}{ A. Mean buy-side herding results } \\
\hline BHM for all funds in database & 11.25 \\
\hline \multicolumn{2}{|c|}{ B. Mean sell-side herding results } \\
\hline SHM for all funds in database & 8.23 \\
\hline
\end{tabular}

The mean herding levels, conditioned on if the proportion of buyers is higher or lower than the average within a quarter, are reported in Table 4 above. Buy-side herding seems to be more prominent than the sell-side herding for our sample of funds. We can conclude that the Indian equity mutual funds tend to herd more often when purchasing a stock. This is similar to the results from some previous studies, e.g. Wylie (2005), but other researchers have also reported the opposite conclusion, e.g. Wermers (1999).

Table 5. Mean herding levels by stock size

\begin{tabular}{|l|l|l|}
\hline HM and difference in mean in percent & Stock Size & $\begin{array}{l}\text { For number of Funds } \\
\text { trading in the quarter }>1\end{array}$ \\
\hline \multicolumn{3}{|c|}{ A. Mean herding results } \\
\hline HM for stock-quarters in subgroup & S1 (small cap) & 5.75 \\
\hline HM for stock-quarters in subgroup & S2 (medium cap) & 7.02 \\
\hline HM for stock-quarters in subgroup & S3 (large cap) & 7.68 \\
\hline \multicolumn{3}{|c|}{ B. Differences mean } \\
\hline Difference in mean & S1- S3 & -1.93 \\
\hline (p-value) & & 0.0425 \\
\hline
\end{tabular}

The paper classifies the traded stocks in sub-groups in terms of market capitalization of the stocks. The stocks have been divided by ranking the stocks on their market value at the beginning of each quarter. Three groups of stocks have been computed, so called small cap, mid cap, and large cap. The Indian mutual funds seem to herd more in large stocks compared to smaller stocks, with an average level of $H M$ in large capitalized stocks of 7.68 percent. In small stocks the funds herd in a level of 5.75 percent and the difference to large stocks is 1.93 percent less. The probability of the two means to be the same is 0.0425 , i.e. the difference in means is significant at the 5 percent level. This contradicts the theories of herding behaviour, which foresees a higher tendency to herd in smaller stocks. Other studies have also received results that could not confirm the theories of more elevated herding in small stocks; see e.g. Walter (2006).

\section{Summary and Conclusions}


The study provides evidence of the tendency of mutual funds in India to form herds while trading the stocks. The overall HM computed over all stock-quarters is 13 percent, under the restriction of at least 1 fund trading a specific stock within the quarter. The result can be interpreted as if 100 funds trade a given stock, then approximately 13 more funds trade on the same side of the market, than would be expected if the fund managers chose their stocks independently as interpreted by earlier study of herding on portugese mutual funds by Júlio Lobão (2002). The Indian mutual funds seem to herd more than the mature markets. The study also concludes that large cap stocks herd more than small caps, which support our Hypothesis. The dataset consists of a clear defined group of funds, investing in the same type of holdings and based on consistent reported snapshots of holdings. Hence, the difference compared to the more developed markets could to some extent depend on those facts applied to a sample of funds during a different time period.

However there are certain limitations of the present study. The sample does not cover a large proportion of the market. As far as the measure is concerned, although it has been used widely, due to its simplicity and conceptual clarity, it carries certain drawbacks. First of all, the LSV measure cannot identify the reason managers are lead to similar decisions (Voronkova and Bohl, 2005). The study has made certain assumptions such as increase or decrease in the NAV (Net Asset Values) of the stocks of a company to determine the buy and sell of a particular stock in comparing the results quarter wise. To make it more reliable the future extension of the study should also track the change in the stock price accompanied with the NAV values to determine the Buy and sell of a stock. Further the study has not taken in to consideration other factors such as stock splits and mergers due to which there is a change in the weight holdings of the portfolios which cannot be truly regarded as buy or sell which should be taken as an adjustment in the further extension of the study.

Evidence on herding by a particular type of investors such as institutional investors, could help in identifying different types or styles of investors with different trading pattern. Investigating herding allows us to further understand investors' thought processes and its effect on their investment decisions such as high market volatility and market destabilization. The future extension should try to study the characteristics of the mutual funds with herding. Such as what is the difference in herding among different size mutual funds and stocks etc. Furthermore, the present study does not measure the effect of the herding behaviour on the stock prices, which is a very important aspect of this issue to explore.

Future research should try to study the factors, which leads to the herding Behavior in Indian Financial Market. After determining the Variable Characteristics such as age, management tenure, size, cash flows, turnover, expenses and previous quarter return. The research should try to find the most closely related characteristic to these herding intensity measures.

Future studies should next investigate whether industry herding is caused by mutual fund managers' attraction to certain industry characteristics such as past returns, size, and book to market. And proceed to examine the impact of herding on mutual fund performance.

Implication of measuring herding in a particular country is that while investing one need to hold larger number of securities in his portfolio to achieve the same degree of diversification 
than in an otherwise normal market where there is no herding. Furthermore, in a market where investors herd stock prices would stop reflecting true values of businesses leading the way to speculative trades. Study has strong implications for the domestic financial institutions, portfolio managers, wealth managers and other investors as well as the policy makers as they shall be interested in understanding the trading behavior of dominant investor group in the market

\section{References}

Agudo, L.F., Sarto, J. L. and Vicente, L. (2008). Herding behavior in Spanish Equity Funds. Applied Economics Letters, 15, 573-576. http://dx.doi.org/10.1080/13504850600706974

Ananthanarayanan, S., Krishnamurthi, C., \& Sen, N. (2004). Foreign Institutional Investors and Security Returns: Evidence from Indian Stock Exchanges, Working Paper, ISB (Indian School of Business), Hyderabad

Angelo Manganaro. (Dick Von Martens2007). Herding Behavior In The Swedish Mutual Fund Industry, Stockholm School Of Economics Master Thesis In Finance

Banerjee, A.V. (1992). a simple model of herd behavior. Quarterly Journal of Economics, 107, 797-817. http://dx.doi.org/10.2307/2118364

Bikhchandani, S., Hirshleifer, D., \& Welch, I. (1992). A theory of fads, fashion, custom, and cultural change as informational cascades. Journal of Political Economy, 100, 992-1026. http://dx.doi.org/10.1086/261849

Chu Ying, \& Qin Ping. (2007). An Empirical Study of Herding Behavior of Mutual Funds in China (Working Paper)

Chang, E. C., Cheng, J. W., \& Khorana, A. (2000). An Examination of Herd Behavior In Equity Markets: An International Perspective. Journal of Banking and Finance, 24(10), 1651 1679. http://dx.doi.org/10.1016/S0378-4266(99)00096-5

Chiyachantana C.N., Jain, P.K. Jiang, C., \& Wood, R.A. (2004). International evidence on Institutional Trading Behavior and Price Impact. The Journal of Finance, LIX(2).

Demirer, R. and Kutan, A. M. (2006). Does Herding Behavior Exist in Chinese Stock Markets?. Journal of International Financial Markets, Institutions and Money, 16(2), pp. 123 142. http://dx.doi.org/10.1016/j.intfin.2005.01.002

De Bondt, W. F. M., \& Forbes, W. P. (1999). Herding in analyst earnings forecasts: evidence from the United Kingdom. European Financial Management, 5, 143-63. http://dx.doi.org/10.1111/1468-036X.00087

Froot, K.A., Scharfstein, D.S., \& Stein, J. C. (1992). Herd on the street: informational inefficiencies in a Model with Short-Term Speculation. Journal of Finance, 67, 1461-84. http://dx.doi.org/10.2307/2328947 


\section{Macrothink}

Asian Journal of Finance \& Accounting

ISSN 1946-052X

2012, Vol. 4, No. 1

Grinblatt, M., Titman, S., \& Wermers, R. (1995). Momentum investment strategies, portfolio performance, and herding: a study of mutual fund behavior. American Economic Review, 85, $1088-105$

Greg N. Gregoriou. (2007). Diversification and Portfolio Management of Mutual Funds, ed., pp 167-197, Palgrave MacMillan, New York 2007, SSRN id 302937

Júlio Lobão, \& Ana Paula. (March 11,2002). Herding Behavior - Evidence from Portuguese Mutual Funds - Serra Thesis Draft

KPMG June. (2009). Indian Mutual Fund Industry: The Future in a Dynamic Environment Outlook for 2015 UNE 2009

Lakonishok, J., Shleifer, A., \& Vishny, R. W. (1992). The impact of institutional trading on stock prices. Journal of Financial Economics, 32, 23-43. http://dx.doi.org/10.1016/0304-405X(92)90023-Q

Lobao, J., \& Serra, A.P. (2002). Herding Behavior - Evidence from Portuguese Mutual Funds.(Working Paper)

Nofsinger, J. R., \& Sias, R. W. (1999). Herding and Feedback Trading by Institutional and Individual Investors. Journal of Finance, 54(6), 22632295.

Oehler, A. (1998). Do Mutual Funds Specializing in German Stocks Herd?, Financial Markets and Portfolio Management, 12(4), pp. 452465 Meng-Fen Hsieh (2010) Positive Trading Effects and Herding Behavior in Asian Markets: Evidence from Mutual Funds. The International Journal of Business and Finance Research, 4(2).

Sharma, V. (2004). Two Essays on Herding in Financial Markets, Ph.D. Dissertation, Virginia Polytechnic Institute \& State University.

Sias, R.W., (2004). Institutional Herding. The Review of Financial Studies, 17(1), 165-206. http://dx.doi.org/10.1093/rfs/hhg035

Walter, A., \& Weber, F. M. (2006), Herding in the German mutual fund industry. European Financial Management, 12, 375-406. http://dx.doi.org/10.1111/j.1354-7798.2006.00325.x

W. Sias Spring. (2004). Institutional Herding Richard. The Review of Financial Studies , $17(1)$, pp. $165 \pm 206$ www.valueresearchonline.com

www.amfiindia.com

www.mutualfundsindia.com 